\title{
Mirascope Luminescent Beam Profile Monitor
}

Cooperative Research and Development Agreement Final Report

CRADA Number: FRA-2018-0038

\section{Fermilab Technical Contact: Randy Thurman-Keup}

Summary Report

October 28, 2019 


\section{NOTICE}

This report was prepared as an account of work sponsored by an agency of the United States government. Neither the United States government nor any agency thereof, nor any of their employees, makes any warranty, express or implied, or assumes any legal liability or responsibility for the accuracy, completeness, or usefulness of any information, apparatus, product, or process disclosed, or represents that its use would not infringe privately owned rights. Reference herein to any specific commercial product, process, or service by trade name, trademark, manufacturer, or otherwise does not necessarily constitute or imply its endorsement, recommendation, or favoring by the United States government or any agency thereof. The views and opinions of authors expressed herein do not necessarily state or reflect those of the United States government or any agency thereof.

Available electronically at http://www.osti.gov/bridge

Available for a processing fee to U.S. Department of Energy and its contractors, in paper, from: U.S. Department of Energy Office of Scientific and Technical Information P.O. Box 62

Oak Ridge, TN 37831-0062

phone: 865.576 .8401

fax: 865.576 .5728

email: mailto:reports@adonis.osti.gov

Available for sale to the public, in paper, from:

U.S. Department of Commerce

National Technical Information Service

5285 Port Royal Road

Springfield, VA 22161

phone: 800.553.6847

fax: 703.605 .6900

email: orders@ntis.fedworld.gov

online ordering: http://www.ntis.gov/ordering.htm 
In accordance with Requirements set forth in Article $X$ of the CRADA, this document is the final CRADA report, including a list of Subject Inventions, to be forwarded to the Office of Science and Technical Information as part of the commitment to the public to demonstrate results of federally funded research.

CRADA number: $\quad$ FRA-2018-0038

CRADA Title: $\quad$ Mirascope Luminescent Beam Profile Monitor

Parties to the Agreement: Muons, Inc. and Fermi Research Alliance, LLC

\section{Abstract of CRADA work:}

Advanced beam diagnostics are essential for reliable operation of high-performance accelerators and the intense beams produced by them. Non-invasive diagnostics can be used continuously with intense beams, while invasive techniques interfere with the beams and distort the beam profiles. In addition, traditional solid-based beam monitoring instrumentation produces unacceptable levels of radiation operating in high power beam environments. Noninvasive determination of accelerated particle distributions and profiles is the most difficult task of bunch diagnostics.

Muons, Inc. proposed to develop non-interfering residual-gas beam profile monitors for transfer lines with pulse-to-pulse precision of better than $0.1 \mathrm{~mm}$ in position and size that will operate over a wide range of proton beam intensities including those needed for multi-MW beams of future facilities.

The approach was to develop a low mass residual-gas profile monitor, where beam induced fluorescence (BIF) will be used to monitor the beam profile. An original scheme of light collection using a mirascope, an optical device invented in the 16th century, is proposed. The gas composition and pressure in the beam pipe are locally controlled to minimize unwanted radiation and to improve resolution.

\section{Summary of Research Results:}

The feasibility of a BIF optical collection system utilizing a mirascope was investigated via raytracing simulations. Light rays were followed from a starting point at the beam, through multiple reflections in the mirascope and through a focusing lens at the exit port of the mirascope. Collection efficiencies were evaluated for various reflectivity and focal lengths of the mirascope as well as positions of the beam within the mirascope. The ability to focus the light was also studied and was dependent on the number of reflections within the mirascope. It was also found that increasing the reflectivity of the mirascope eventually results in a plateau in the collection efficiency since the light is lost at the holes that are necessary for the beam to pass 
through. If one can focus all the light, then the gain in optical intensity using the mirascope relative to no mirascope is around a factor of 9 . If one cannot focus all the light, then the gain is a more modest factor of 3 .

Related Reports, Publications, and Presentations:

Dudnikov, V., Abrams, R., and Cummings, M.A.C., "Mirascope Residual-Gas Luminescent Beam Profile Monitors", Vancouver, BC, Canada, IPAC2018.

http://accelconf.web.cern.ch/AccelConf/ipac2018/papers/wepa1051.pdf

\section{Subject Inventions listing:}

NONE

Report Date: October 28, 2019

Technical Contact at Fermilab: Randy Thurman-Keup

This document contains NO confidential, protectable or proprietary information. 